\title{
Hubungan antara Infeksi Cacing dan Alergi
}

\author{
Yolazenia $^{1}$, Taniawati Supali ${ }^{2}$, Heri Wibowo ${ }^{3}$
}

\begin{abstract}
Many researches showing the evidence of a reverse relation between helminthiasis and allergic diseases in tropical developing countries, supported by hygiene hypothesis. There is relationship between the inflammation caused by allergic and helminthiasis. Both, allergic and helminthiasis, show the increase of IgE level, eosinophilia, mastocytosis, and release of IL-4, IL-5 and IL-13 cytokines by Th2. Several mechanisms explaining the decrease of allergic manifestation in people with helminthiasis are polyclonal IgE blocking, suppression of anti-inflammatory cytokines (IL-10 and TGF-â), and IgG4 blocking antibody.
\end{abstract}

Keywords: helminthiasis, allergic diseases, IgE, anti-inflammatory cytokines, IgG4

Parasit cacing menginfeksi lebih dari dua milyar orang di seluruh dunia dan menyebabkan morbiditas dan disabilitas yang cukup berarti. Infeksi cacing tidak menjadi masalah kesehatan masyarakat lagi di negara maju karena berhasilnya program pengendalian, seperti pemberantasan populasi vektor, sistem pembuangan kotoran manusia yang tertata baik, dan penyediaan obat-obat antihelmintik yang efektif. Sayangnya, di negara berkembang, program pengendalian ini masih belum dapat berjalan dengan baik sehingga infeksi cacing masih merupakan masalah kesehatan masyarakat yang penting. ${ }^{1,2}$

Penyakit alergi (asma, rhinitis, dan ekzema) justru meningkat di negara industri/maju. Terdapat peningkatan prevalensi yang berarti dalam 2-3 dekade terakhir. Data terkini menunjukkan bahwa lebih dari 130 juta orang menderita asma, dan jumlahnya terus meningkat. Di negara sedang berkembang, prevalensi penyakit alergi ini cenderung rendah. ${ }^{3}$

Berdasarkan hal tersebut di atas maka timbul pertanyaan apakah ada hubungan antara rendahnya

\footnotetext{
1 Alamat korespondensi: Bagian Parasitologi FK Universitas Riau. Jl.Diponegoro No.1, Pekanbaru.

Email: yolazenia@yahoo.com

${ }^{2,3}$ Bagian Parasitologi Kedokteran Fakultas Kedokteran

Universitas Indonesia
}

prevalensi penyakit cacing dengan meningkatnya penyakit alergi di negara maju, atau sebaliknya tingginya prevalensi penyakit cacing dengan rendahnya penyakit alergi di negara sedang berkembang? Banyak perhatian ditujukan pada hipotesis bahwa rendahnya prevalensi asma dan penyakit alergi lain yang diamati pada masyarakat di daerah tropis terpencil mungkin disebabkan adanya efek proteksi dari infeksi cacing usus. Beberapa penelitian menunjukkan bukti terdapatnya hubungan terbalik antara infeksi parasit dan penyakit alergi di negara tropis yang sedang berkembang, seperti di Kenya, Ethiopia, Ekuador, dan Venezuela, dan Indonesia. ${ }^{4,13}$

Tidak semua penelitian mendukung adanya hubungan terbalik antara helminthiasis dengan alergi. Penelitian lain menemukan tidak ada penurunan insiden alergi pada individu dengan helminthiasis, atau pada beberapa kasus justru tinggi, seperti yang ditemukan di China. ${ }^{14,16}$ Oleh karena itu hubungan antara helminthiasis dengan alergi masih menjadi kontroversi. Pada tulisan ini akan dibahas mengenai hubungan infeksi cacing dan alergi, disertai mekanisme imunologis yang mendasarinya. 


\section{INFEKSI CACING}

Parasit cacing usus tersebar di seluruh dunia dan diperkirakan menginfeksi sekitar sepertiga dari penduduk. Infeksi cacing usus adalah infeksi yang paling tinggi prevalensinya dan persisten di antara semua infeksi pada masa anak-anak dan kebanyakan orang yang tinggal di area endemik pasti pernah terinfeksi serta banyak yang mengalami infeksi terus-menerus sejak dilahirkan sampai dewasa. ${ }^{17}$

Infeksi cacing atau disebut juga helminthiasis dapat disebabkan oleh cacing yang tergolong dalam kelas Nematoda, Trematoda, dan Cestoda. Prevalensi infeksi terbanyak disebabkan oleh cacing dari kelas Nematoda, yaitu: Ascaris lumbricoides, Trichuris trichiura, dan cacing tambang. Infeksi oleh A. lumbricoides dan T. trichiura didapat pada umur muda dengan prevalensi dan intensitas mencapai puncak antara umur 5-15 tahun. Infeksi cacing tambang biasanya dimulai pada saat anak mulai bisa berjalan, dan prevalensi puncaknya terjadi kemudian. Intensitas transmisi cacing dan pola transmisinya dari tahun ke tahun merupakan determinan penting terhadap timbulnya respon imun hospes terhadap parasit dan hubungan respon imun alamiah antara infeksi cacing dan alergi. ${ }^{17}$

Petanda terjadi infeksi cacing secara imunologik adalah peningkatan IgE dan eosinofilia. Kadar IgE total dapat melebihi kadar pada pasien asma atau dermatitis atopik, dan jumlah eosinofil dalam rentang antara pertengahan sampai amat tinggi (lebih dari $40.10^{9} / \mathrm{L}$ ). Infeksi cacing usus juga berhubungan dengan hiperplasia sel mast. ${ }^{18}$

Pada awalnya, infeksi cacing usus menimbulkan respon inflamasi yang sama seperti yang disebabkan alergen lingkungan. Sel T CD 4+ memegang peranan utama dalam mengatur respon inflamasi akibat parasit cacing, terutama nematoda usus. Sel T dapat berfungsi untuk merekrut dan mengaktivasi sel-sel efektor, yang sama pada reaksi alergi. ${ }^{1,2,19,20}$

Antigen parasit menginduksi antibodi $\operatorname{IgE}$ antiparasit. Sel mast mengalami degranulasi saat antibodi IgE berada pada permukaannya untuk berinteraksi dengan antigen. Konsentrasi IgE yang tinggi pada infeksi cacing usus dapat mesaturasi lebih dari $100.000 \mathrm{Fc}$ reseptor IgE pada sisi yang berikatan dengan sel mast untuk mencegah pengikatan dengan molekul IgE lain. Kadar tinggi IgE yang diinduksi cacing berlawanan dengan lemahnya antigenisitas yang berhubungan dengan alergen udara. Hal inilah mungkin menyebabkan timbulnya paradoks bahwa pada daerah rural (nonwestern, non industry) ditemukan total $\mathrm{IgE}$ serum yang sangat tinggi, dan penderita asma yang sedikit. Pada infeksi cacing umumnya juga terjadi peningkatan eosinofil di darah perifer dan jaringan, terutama pada cacing dengan fase invasi ke jaringan. Tapi hanya sedikit data yang mendukung peran proteksi eosinofil terhadap infeksi cacing in vivo. Umumnya, pemikiran bahwa tingginya eosinofil dalam darah merupakan refleksi dari kepadatan cacing. ${ }^{1,2,19,20}$

Untuk penyebarannya, cacing membutuhkan hospes yaitu manusia. Morbiditas hospes sangat tergantung pada kepadatan parasit. Fenomena alergi jarang pada individu dengan infeksi kronik, dan respon imunnya berbeda dari fenotip akut dengan respon Th2 lebih terpolarisasi, sekresi sejumlah besar sitokin imunosupresif seperti IL-10 dan TGFâ. Pada infeksi kronik, kadar total IgE lebih tinggi dibandingkan kadar IgE spesifik parasit. ${ }^{19}$

Semua cacing usus dengan siklus paru, seperti A. lumbricoides, cacing tambang, dan S. Stercoralis, dapat menyebabkan sindrom seperti asma (sindrom Löeffler), dengan gejala sesak nafas, batuk, dan eosinofilia. Askariasis juga berhubungan dengan ruam alergi dan anafilaksis akut walaupun bentuk ini mungkin lebih umum pada infeksi yang larvanya bermigrasi lebih luas di jaringan seperti $S$. stercoralis dan sindrom larva migran. Pada daerah dengan infeksi cacing A. lumbricoides bersifat musiman, gejala askariasis paru mungkin relatif umum. Di daerah dengan askariasis endemik tinggi, dan infeksi didapat pada umur awal, gejala askariasis paru lebih jarang dijumpai. ${ }^{17}$

Salah satu hal yang penting dalam mengamati hubungan antara infeksi cacing usus dengan alergi adalah epidemiologi infeksi cacing di area tertentu, yaitu area dengan transmisi cacing usus bersifat sporadik atau musiman mempunyai prevalensi rendah dan akut maka gejala alergi lebih menonjol, sedangkan di area dengan transmisi terus-menerus mempunyai prevalensi tinggi dan kronik maka respon alergi dapat ditekan oleh infeksi. ${ }^{17}$ 


\section{ATOPI DAN ALERGI}

Penyakit alergi pada manusia dapat berupa asma, rhinitis, ekzema, dan alergi makanan. Penyakit alergi sangat berkaitan dengan adanya atopi. Atopi adalah suatu keadaan yang mengindikasikan meningkatnya risiko seseorang mengalami penyakit alergi. Atopi ditandai dengan peningkatan kadar total antibodi IgE dan IgE spesifik terhadap alergen tertentu, dan bukti in vivo adanya IgE-mediated hipersensitivitas cepat yang dibuktikan dengan uji kulit (skin prick test) dengan alergen yang sama. ${ }^{13,17,19}$

Banyak peneliti percaya bahwa atopi adalah determinan yang penting terhadap asma alergi walaupun hanya $25-30 \%$ individu yang atopi di negara industri yang penyakit alerginya benar-benar berkembang secara klinis. Kira-kira 37\% asma berhubungan dengan atopi pada penduduk. Faktor yang menyebabkan hanya sebagian individu atopi yang berkembang secara klinik belum diketahui walaupun faktor lingkungan sepertinya berperan penting. ${ }^{17}$ Alergen lingkungan umumnya dapat merangsang respon IgE yang menyebabkan pelepasan histamin dan substansi aktif lainnya oleh sel mast. Portal utama tempat masuknya alergen adalah: kulit, paru, dan usus, juga di tempat-tempat yang terdapat IgE yang disekresi sel B. ${ }^{13}$

Perkembangan penyakit alergi dapat dibagi ke dalam fase induksi dan efektor. Fase induksi ditandai dengan kecenderungan respon sel $\mathrm{T}$ terhadap fenotip Th2, peningkatan produksi IgE, sel mast dan eosinofil. Hasilnya bermanifestasi pada fase efektor, dan beberapa komponen respon Th2 mencetuskan inflamasi aktif. Proses inflamasi sendiri bisa bifasik. Pertama, degranulasi sel mast melepaskan mediator yang menimbulkan efek farmakologi pada jaringan sekitarnya dan aksi kemotaktik, yang menyebabkan inflamasi kedua dengan merekrut eosinofil, monosit, neutrofil dan limfosit. Sel yang direkrut ini, pada saatnya, melepaskan sejumlah besar sitokin, yang lebih lanjut mengacaukan homeostasis jaringan. Hal ini secara gamblang ditunjukkan pada bronchial airways dimana interleukin-13 (IL-13) merangsang produksi mukus oleh sel goblet dan merangsang kontraksi sel otot polos oleh Tumor Necrosis Factor $\alpha(\mathrm{TNF}-\alpha)$ dapat mencapai puncak pada serangan asma berat. ${ }^{19}$
Prevalensi penyakit alergi jauh lebih banyak ditemukan di negara industri barat dibandingkan di negara sedang berkembang. Di daerah tropik, terdapat perbedaan besar pada prevalensi alergi antara daerah kota (urban) dan desa (rural) dengan angka asma lebih tinggi pada populasi urban. ${ }^{17}$ Pola insiden penyakit atopi di dunia menunjukkan peningkatan gradien dari daerah berkembang dan terpencil ke daerah yang lebih makmur, industrialisasi dan urban. Sebanyak 10-30\% dari total populasi di negara maju diketahui menderita alergi secara klinik. ${ }^{19}$

Meningkatnya insiden atopi dan penyakit alergi hingga dua kali lipat dalam 20 tahun ini menjadi perhatian utama dalam dunia kedokteran sekarang. Hal ini tidak dapat hanya dihubungkan karena perbaikan dalam menegakkan diagnosis penyakit ini. 19

Namun demikian banyak individu yang terbebas dari manifestasi klinik alergi meskipun memiliki semua elemen yang dianggap perlu untuk mencetuskan penyakit alergi. Hal ini dapat dilihat pada subjek yang terinfeksi cacing, yang respon Th2 mendominasi sehingga tidak ada alergi klinik. Petanda respon ini termasuk peningkatan produksi IL-4, peningkatan kadar IgE serum, dan eosinofilia. Penelitian mengenai pengaruh infeksi cacing terhadap alergi mungkin dapat mengungkapkan faktor-faktor yang sukar dipahami yang mengendalikan progresifitas penyakit. ${ }^{19}$

\section{HIPOTESIS HYGIENE}

Hipotesis hygiene pertama kali dikemukakan Strachan pada tahun 1989 yang menyatakan bahwa penyakit alergi dapat dicegah oleh infeksi pada awal masa kanak-kanak, sedangkan menurunnya jumlah anggota keluarga, standar hidup yang lebih baik, kebersihan perorangan telah menurunkan kesempatan terjadinya infeksi silang pada anakanak, yang dapat menghasilkan lebih menyebarnya kejadian klinik penyakit atopi. Hipotesis ini banyak menimbulkan perdebatan. Dalam 10 tahun terakhir ini banyak penelitian yang dilakukan berdasarkan hipotesis ini. Setelah 10 tahun, Strachan tetap berpegang pada pendapatnya bahwa infeksi merupakan faktor proteksi dari penyakit alergi. ${ }^{21,22}$

Setelah beberapa abad, infeksi serius pada masa 
anak di negara industri, insidennya menurun drastis seiring dengan perbaikan hygiene, vaksinasi dan penggunakan antibiotik. Sedikitnya infeksi berat pada anak-anak ini mungkin disebabkan penghambatan respon Th1 yang kuat, menyebabkan ekspansi Th2 dari sistem imun, langsung terhadap alergen lingkungan. ${ }^{19}$

Paparan terhadap patogen makanan dan oralfecal, seperti hepatitis A, Toxoplasma gondii, dan Helicobacter pylori, menurunkan risiko atopi sampai $>60 \% .^{22}$ Hubungan terbalik yang kuat juga ditemukan antara hipersensitifitas lambat terhadap Mycobacterium tuberculosis (respon tuberkulin) dengan atopi pada anak-anak Jepang. Respon tuberkulin positif ini memprediksikan rendahnya insiden asma, kadar IgE serum dan profil sitokin sel Th1. Profil yang sama juga ditemukan di negara lain. Data eksperimental pada tikus menunjukkan hambatan utama antigen yang menginduksi asma oleh pre-exposure terhadap BCG (Bacilus CalmetteGuerin). ${ }^{3,14,19}$

Pemberian terapi anthelmintik secara teratur pada anak-anak di area kumuh di Caracas, Venezzuela, dengan helminthiasis endemik, menyebabkan meningkatnya insiden hipersensitifitas cepat terhadap alergen lingkungan. ${ }^{4}$ Data ini memberikan dukungan yang kuat terhadap hipotesis hygiene. Modifikasi lebih lanjut terhadap hipotesis ini telah menimbulkan argumentasi bahwa infeksi akut satu episode kurang signifikan dibandingkan perubahan dinamis yang disebabkan beberapa patogen yang secara persisten merangsang imunitas mukosa dan menginduksi respon Th1 yang cukup untuk mencegah atopi. Bagaimanapun, untuk membuktikan korelasi penyakit autoimun dengan infeksi cacing, perlu di evaluasi kembali dasar imunologi dari hipotesis hygiene. ${ }^{3}$

\section{HUBUNGAN INFEKSI CACING DAN ALERGI}

Ada pertanyaan yang timbul mengenai apakah benar insiden alergi lebih rendah pada orang dengan infeksi cacing. Beberapa penelitian menunjukkan hasil yang mendukung hal tersebut. Terdapat hubungan paralel yang kuat antara inflamasi yang disebabkan penyakit alergi dan yang disebabkan infeksi parasit cacing. Keduanya, baik alergi maupun infeksi cacing berhubungan dengan peningkatan kadar IgE, eosinofilia jaringan, mastositosis, dan sel Th2 yang mensekresi sitokin IL-4, IL-5 dan IL-13. Walaupun infeksi cacing dan penyakit atopi dihubungkan dengan fenomena imunologi yang sama, klinik yang muncul tidaklah sama. ${ }^{3,17,19}$ Beberapa penelitian yang mengevaluasi pendapat bahwa infeksi cacing punya efek proteksi terhadap alergi di Amerika Selatan dan Afrika dengan menggunakan parameter untuk menilai alergi dan diagnosis parasitologik yang akurat menunjukkan hubungan terbalik yang konsisten antara infeksi cacing dengan baik reaksi kulit terhadap alergen lingkungan maupun skor klinik, seperti hiperresponsif jalan nafas, wheezing, dan asma. $^{3}$

Lynch dkk meneliti efek pemberian terapi antihelmintik secara teratur selama 22 bulan pada anak-anak yang punya fenotipe alergi di area kumuh di Caracas, Venezuela. Pemberian terapi terhadap infeksi cacing pada penelitian ini menghasilkan penurunan kadar IgE total serum yang signifikan yang disertai dengan peningkatan reaktivitas uji kulit dan kadar antibodi IgE spesifik serum terhadap aeroalergen lingkungan. ${ }^{4}$

Khusus untuk asma, Lynch dkk meneliti efek pemberian terapi antihelminthik secara teratur dengan albendazole selama 1 tahun pada sekelompok pasien asma di area endemik parasit. Perbaikan yang bermakna dapat dilihat pada semua indikator status klinik pada kelompok yang mendapat terapi, tidak hanya selama masa pemberian antihelmintik melainkan juga setahun berikutnya, tetapi setelah 2 tahun tanpa terapi serangan asma kembali ke fase awal. Tidak terlihat perubahan yang bermakna pada kelompok kontrol selama periode penelitian ini. Walaupun kadar total IgE serum meningkat pada awal penelitian kemudian menurun secara bermakna setelah pemberian antihelmintik, kadar antibodi IgE spesifik dan uji kulit positif yang dihasilkan dari tungau debu rumah juga menurun. Kita dapat berspekulasi bahwa hal ini disebabkan oleh efek non spesifik sebagai akibat terapi atau hasil langsung eradikasi parasit. ${ }^{5}$

Lynch dkk juga meneliti hubungan infeksi cacing dan respon IgE pada anak-anak dengan latar belakang atopi di Pulau Coche dan non-atopi di Barrio Los Erasos, Venezuela dengan kondisi hidup 
yang hampir sama. Prevalensi infeksi Ascaris pada kedua grup ini hampir sama yaitu Coche $51 \%$ dan Barrio 57\%, tapi intensitas infeksinya jauh lebih tinggi pada anak non-atopi. Kadar IgE total serum pada kelompok non-atopi juga lebih tinggi dibanding kelompok atopi. Sebaliknya respon spesifik antiAscaris lebih tinggi pada anak atopi. Hal tersebut menyimpulkan bahwa anak dengan latar belakang atopi menunjukkan respon IgE yang sesuai dengan intensitas infeksi yang lebih rendah daripada anak dari daerah non atopi. ${ }^{6}$

Penelitian di Jimma, Ethiopia oleh Scrivener dkk pad tahun 1999 menemukan bahwa risiko wheezing secara independen menurun pada infeksi cacing tambang. ${ }^{7}$ Di daerah yang sama Dagoye D dkk melakukan penelitian case control pada 7155 anak umur 1-4 tahun di daerah urban dan rural dan menemukan bahwa prevalensi anak dengan gejala wheezing lebih sering ditemukan di daerah urban $(4,4 \%)$ daripada rural $(2,0 \%)$, dan lebih sedikit ditemukan pada anak yang terinfeksi Ascaris. ${ }^{8}$

Penelitian pada anak-anak sekolah dengan infeksi Schistosoma haematobium di Gabon menunjukkan bahwa risiko uji kulit positif terhadap tungau debu rumah lebih rendah $63 \%$ dibandingkan yang tidak terinfeksi. ${ }^{9}$ Dibandingkan area urban di Kenya, anak yang tinggal di area rural, respon uji kulit terhadap alergi lebih rendah, prevalensi antibodi IgE terhadap Ascaris lebih tinggi (67\% vs $26 \%$ ), dan total IgE 10 kali lebih tinggi. ${ }^{10}$

Cooper dkk meneliti 2865 anak sekolah umur 5-19 tahun dari 55 sekolah di daerah tropis rural di Equador dan menunjukkan adanya efek proteksi infeksi cacing terhadap alergen uji kulit. ${ }^{11}$ Penelitian yang lebih besar di daerah yang sama yaitu melibatkan 4433 anak dari 71 sekolah menunjukkan bahwa prevalensi gejala alergi rendah $(2,1 \%)$, tapi prevalensi reaktifitas uji kulit relatif tinggi $(18,2 \%)$. Infeksi cacing merupakan faktor proteksi terhadap alergen uji kulit, tapi tidak terhadap gejala alergi (wheezing, rhinitis, ekzema atopik). ${ }^{12}$

Penelitian yang dilakukan di daerah perkotaan yaitu Palembang (Indonesia) ditemukan prevalensi alergi relatif tinggi (44\%), dan dari 59 anak yang diperiksa cacingnya hanya 7 yang positif $(11,8 \%)$. Dari 7 yang positif ini hanya 1 yang uji kulit nya positif (14\%) sedangkan pada yang tidak terinfeksi cacing $38 \%$ uji kulit positif. ${ }^{13}$
Tidak semua penelitian menunjukkan hubungan terbalik antara infeksi cacing dan alergi. Ada penelitian yang tidak menemukan terjadinya penurunan insiden alergi pada individu dengan infeksi cacing, atau pada beberapa kasus insiden penyakit alergi justru meningkat. Survei epidemiologi di kota kecil propinsi Jiangsu, China menunjukkan bahwa setelah pemerintah China memulai kampanye pemberian obat cacing di sekolah-sekolah pada tahun 1997, prevalensi $A$. lumbricoides menurun drastis dari $60 \%$ sampai mendekati nol pada tahun 1999. Seiring dengan itu, insiden penyakit alergi dan reaksi kulit terhadap alergen pada anak-anak sekolah tersebut tidak mengalami peningkatan dalam 3 tahun yang sama. ${ }^{14}$ Penelitian di Provinsi Anqing (daerah rural), China menunjukkan bahwa infeksi A. lumbricoides berhubungan dengan peningkatan risiko asma dan peningkatan jumlah uji kulit positif terhadap aeroallergen. ${ }^{15}$ Harminarti dkk juga menemukan tidak ada hubungan antara infeksi cacing usus dengan manifestasi atopi pada anak Sekolah Dasar di desa Anaranda dan Nangapanda, kabupaten Ende, Flores, Nusa Tenggara timur (NTT). ${ }^{16}$

Melihat ketimpangan dan kompleksitas pengaruh dari infeksi cacing terhadap alergi ini diperlukan penelitian untuk mengevaluasi faktorfaktor pengganggu seperti jenis dan kepadatan cacing, dan status sosial ekonomi. Seperti di Venezuela, anak dengan intensitas infeksi cacing yang rendah menunjukkan prevalensi asma dan uji kulit terhadap alergen yang lebih tinggi. Tetapi setelah pemberian terapi anthelmintik perbedaan ini menghilang. ${ }^{4,5}$ Kepadatan cacing juga bergantung kepada status sosial ekonomi. Dengan mengontrol faktor sosial ekonomi, Lynch dkk menunjukkan bahwa anak-anak dari orang tua kaya menunjukkan prevalensi penyakit alergi lebih tinggi dibanding dengan anak yang tinggal di daerah kumuh, dan juga memiliki kepadatan telur A. lumbricoides lebih sedikit. ${ }^{4}$ Jadi, infeksi cacing dengan intensitas rendah dapat mencetuskan timbulnya alergi sedangkan infeksi berat dapat menghambatnya. Kepadatan dan kronisitas infeksi cacing adalah variabel penting yang dapat menentukan apakan cacing bertindak sebagai faktor risiko atau proteksi terhadap penyakit alergi. ${ }^{3}$ 


\section{MEKANISME IMUNOLOGIS YANG MENDASARI HUBUNGAN TERBALIK ANTARA INFEKSI CACING DAN ALERGI}

Hipotesis sentral yang menerangkan berkurangnya manifestasi alergi pada individu yang terinfeksi cacing adalah "hipotesis penghambatan IgE”. Disebabkan tingginya kadar IgE poliklonal tidak spesifik yang dipicu oleh antigen parasit pada kebanyakan infeksi cacing, para peneliti mengatakan bahwa beberapa reseptor Fc å tipe I (FcåRI) pada sel mast tidak dapat ditempati oleh molekul IgE terhadap alergen manapun. Jika IgE, yang tidak ada antigen yang tersedia, mensaturasi FcåRI pada sel mast dan menghambat pengikatan IgE spesifik langsung terhadap antigen parasit atau alergen lingkungan, dapat menghambat degranulasi dan respon hipersensitivitas cepat terhadap alergen. Respon degranulasi sel mast memerlukan hubungan silang antara 2 molekul IgE-FcåRI yang berikatan dengan suatu alergen, sehingga memproduksi banyak IgE yang irrelevan yang akan menghambat respon alergi terhadap tungau debu rumah (TDR). Dukungan terhadap hipotesis ini datang dari penelitian yang melibatkan pemberian terapi antihelmintik pada anak-anak yang menunjukkan reaktivitas kulit paralel dengan penurunan kadar IgE total yang bermakna. . $^{3,419,24}$

Penelitian yang lebih baru pada manusia, meragukan penjelasan yang melibatkan IgE non spesifik ini. Penelitian pada anak sekolah yang menderita infeksi cacing jaringan yaitu skistosomiasis dan filariasis menunjukkan tingginya tingkat sensitisasi terhadap tungau debu rumah: tiga puluh dua persen (32\%) dari anak yang diteliti punya kadar antibodi anti-TDR IgE $>1 \mathrm{IU} / \mathrm{mL}$. Tapi jauh lebih sedikit anak yang menunjukkan gejala fisik alergi yaitu $11 \%$ uji kulit positif dan hanya 3\% menunjukkan hiperresponsif bronkus. Anak dengan infeksi menunjukkan reaktivitas terhadap TDR yang jauh lebih rendah dari anak-anak yang bebas infeksi (8\% banding $17 \%$ ). Penelitian ini juga memasukkan status sosioekonomi, gizi, kadar IgE total yang meningkat sangat tinggi, tidak menunjukkan hubungan yang bermakna pada reaktivitas kulit terhadap TDR. ${ }^{9}$

Infeksi cacing mempunyai dimensi tambahan sebagai antigen kronik, dan pengaturan sistem imun mungkin merupakan respon alamiah terhadap paparan antigen yang terus-menerus. Rangsangan persisten imunitas mukosa pada organ seperti paru dan usus 'mendidik' sistem imun pada organ ini untuk bereaksi terhadap alergen. Profil imun ini bukan merupakan rangsangan respon Th1 tapi dicetuskan oleh strong regulatory dan/atau antiinflammatory network. Network ini akan melepaskan sitokin seperti IL-10 dan transforming growth factor $\hat{a}$ (TGF-â) yang menurunkan inflamasi jalan nafas dengan beberapa mekanisme: penurunan degranulasi sel mast, penurunan produksi sitokin pro-inflammatory dan penurunan reaktivitas selsel jalan nafas terhadap inflamasi. ${ }^{19}$ Dua sitokin antiinflamasi yang paling penting adalah IL-10 dan TGF-â. IL-10 dan TGF-â downregulate imunitas seluler dan inflamasi alergi. Pengurangan sekresi sitokin ini dapat menyebabkan berkembangnya alergi dan asma. Kebalikan dari efek anti inflamasinya, terdapatnya IL-10 dan TGF-â pada proses alergi yang sedang berlangsung dapat menyebabkan keparahan penyakit dengan menstimulasi sintesis IgE dan fibrosis., ${ }^{2,19,25}$ Telah dilaporkan bahwa individu yang mengalami alergi menunjukkan level IL-10 yang lebih rendah. Anak dengan infeksi schistosoma menunjukkan level IL10 tinggi yang menurunkan risiko berkembangnya reaktivitas kulit terhadap alergen. ${ }^{9}$ TGF-â juga produk anti inflamasi yang utama dan bila ditransfeksikan ke sel T dapat downregulate tidak hanya Th1 tapi juga Th2 yang memediasi inflamasi. ${ }^{18}$ TGF-â, seperti IL-10, secara tidak langsung menghambat aktivasi sel $\mathrm{T}$ dengan memodulasi fungsi antigen presenting cell (APC) dan deaktifasi makrofag. TGF-â dapat membantu mencegah perkembangan inflamasi alergi melalui kemampuannya untuk menghambat sintesis IgE dan melalui penghambatan proliferasi sel mast. ${ }^{25}$ Oleh karena itu, adanya anti-inflammatory network selama infeksi cacing kronik mungkin merupakan kunci pada rendahnya prevalensi penyakit alergi. ${ }^{19}$

Penghambatan reaktivitas alergi secara klinis sepertinya juga hasil Ag-specific IgG "blocking antibodies" yang banyak ditemukan pada serum penderita infeksi cacing kronis. Penelitian pada penderita filariasis menunjukkan korelasi yang bermakna dengan aktivitas penghambatan ini yang hanya terlihat untuk antibodi subkelas $\operatorname{IgG} 4$, dan hubungannya sangat kuat pada kelompok pasien asimtomatik tapi dengan mikrofilaria $(+)$ dalam 
darah yang memiliki kadar antibodi blocking tertinggi. ${ }^{26}$

\section{PENUTUP}

Penyakit alergi di negara industri maju menunjukkan peningkatan prevalensi yang berarti dalam 2-3 dekade ini, sedangkan di negara tropis terutama daerah pedesaan (rural) prevalensinya jauh lebih rendah. Sebaliknya, infeksi cacing prevalensinya justru tinggi di daerah tropis pedesaan (rural). Terdapat bukti dari penelitian epidemiologi yang berbeda bahwa infeksi cacing dapat memodulasi atopi/penyakit alergi, yaitu dapat sebagai proteksi terhadap atopi/alergi pada suatu populasi atau dapat sebagai faktor risiko atopi/alergi pada populasi lain. Penjelasan terhadap kontradiksi ini mungkin pada paradigma dimana infeksi cacing akut dapat meningkatkan reaktivitas alergi sedangkan infeksi kronik dapat menekan inflamasi alergi. Infeksi cacing akut menimbulkan reaksi alergi langsung terhadap antigen parasit maupun nonparasit (seperti:alergen lingkungan). Penekanan atopi/alergi pada individu dengan infeksi cacing kronik dapat terjadi melalui beberapa mekanisme seperti saturasi sel mast oleh IgE polyclonal, peningkatan produksi sitokin anti-inflamasi (IL-10 dan TGF-â), dan penghambatan oleh IgG4.

Pengaruh infeksi cacing terhadap alergi sepertinya bervariasi antar daerah yang berbeda dan bahkan antar komunitas berbeda pada area yang sama bergantung kepada endemisitas infeksi dengan parasit cacing berbeda dan kelompok studi yang dipilih. Jadi, hubungan antara infeksi cacing dan alergi ini sangat kompleks, dan terdapat banyak pertanyaan yang belum terjawab menyangkut aturan modulasi infeksi cacing terhadap atopi/alergi.

\section{DAFTAR PUSTAKA}

1. MacDonald AS, Araujo MI, Pearce EJ. Immunology of parasitic helminth infections. Infection and Immunity 2002;70:427-433.

2. Maizels RM, Yazdanbakhsh M. Immune regulation by helminth parasites: Cellular and molecular mechanisms. Nature Reviews 2003;3:733-744.
3. Yazdanbakhsh M, Kremsner PG, Van Ree R. Allergy, parasites, and the hygiene hypothesis. Science 2002;296:490-4.

4. Lynch NR, Hagel I, Perez M, et al. Effect of anthelmintic treatment on the allergic reactivity of children in a tropical slum. J Allergy Clin Immunol 1993;92:404-411.

5. Lynch NR, Palenque M, Hagel I, DiPrisco MC. Clinical improvement of asthma after anthelmintic treatment in a tropical situation. Am J Respir Crit Care Med 1997;156:50-4.

6. Lynch NR, Hagel I, Palenque M, et al. Relationship between helminthic infection and $\mathrm{IgE}$ response in atopic and nonatopic children in a tropical environment. J Allergy Clin Immunol 1998;101:217-221.

7. Scrivener S, Yemaneberhan H, Zebenigus M, et al. Independent effects of intestinal parasite infection and domestic allergen exposure on risk of wheeze in Ethiopia: a nested case-control study. Lancet 2001;358:1493-9.

8. Dagoye D, Bekele Z, Woldemichael K, et al. Wheezing, allergy, and parasite infection in children in urban and rural Ethiopia. Am J Respir Crit Care Med 2003;167:1369-1373.

9. Biggelaar AHJ, Ree R, Rodrigues LC, et al. Decreased atopy in children infected with Schistosoma haematobium: a role for parasiteinduced interleukin-10. Lancet 2000;356:17237.

10. Perzanowski MS, Ng'ang'a LW, Carter MC, et al. Atopy, astma, and antibodies to Ascaris among rural and urban children in Kenya. Journal of Pediatrics 2002;140:582-8.

11. Cooper PJ, Chico ME, Rodrigues LC, et al. Reduced risk of atopy among school- age children infected with geohelminth parasites in a rural area of the tropics. J Allergy Clin Immunol 2003;111:995-1000.

12.Cooper PJ, Chico ME, Bland M, Griffin GE, Nutman TB. Allergic symptoms, atopy, and geohelminth infections in a rural area of Ecuador. Am J Respir Crit Care Med 2003;168:313-7.

13.Steekelenburg M. Prevalence of allergy and relationship with IgE levels, helminth infections 
and living conditions in Palembang, Indonesia. A hospital- based study, 1999.

14.Mao XQ, Sun DJ, Miyoshi A, et al. The link between helminth infection and atopy. Parasitology today 2000;16:186-8.

15.Palmer LJ, Celedon JC, Weiss ST, et al. Ascaris lumbricoides infection is associated with increased risk of childhood asthma and atopy in rural China. Am J Respir Crit Care Med 2002;165:1489-1493.

16.Harminarti N, Supali T, Wibowo H. Hubungan infeksi cacing usus dan atopi pada anak sekolah dasar. Majalah Kedokteran Andalas 2008;32(1):55-64.

17.Cooper PJ. Can intestinal helminth infections (geohelminths) affect the development and expression of astma and allergic disease? Clin Exp Immunol 2002;128:398-404.

18. Yazdanbakhsh M. IgE, eosinophils and mast cells in helminth infections. Ned Tijdschr Klin Chem 1996;21:213-6.

19. Yazdanbakhsh M, Biggelaar A, Maizels RM. Th2 responses without atopy: immunoregulation in chronic helminth infections and reduced allergic disease. Trend in immunology 2001;22:372-7.
20.Weiss ST. Parasite and asthma/allergy: What is the relationship? J Allergy Clin Immunol 2000;105:205-210.

21.Strachan DP. Hay fever, hygiene, and household size. BMJ 1989;299:1259-60.

22.Strachan DP. Family size, infection and atopy: the first decade of the "hygiene hypothesis". Thorax 2000;55:S2-S10.

23.Matricardi PM, Rosmini F, Riondino S, et al. Exposure to foodborne and orofecal microbes versus airborne viruses in relation to atopy and allergic astma: epidemiological study. BMJ 2000;320:412-17.

24.Lynch NR. Parasite infections and the risk of asthma and atopy. Thorax 1999; 54:659-60.

25.Hobbs K, Negri J, Klinnert M, Rosenwasser LJ, Borish L. Interleukin-10 and transforming growth factor-â promoter polymorphisms in allergies and asthma. Am J Respir Crit Care Med 1998;158:1958-62.

26. Hussain R, Poindexter RW, Ottesen EA. Control of allergic reactivity in humman filariasis. Predominant localization of blocking antibody to the IgG4 subclass. The Journal of Immunology 1992;148:2731-7. 